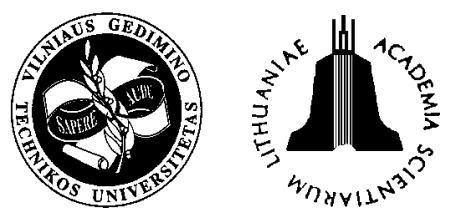

\title{
METHODS FOR OPTIMIZATION OF ROTATIONAL LATENCY OF THE INVERSE LOADING OF TRUCKS ON INTERNATIONAL ROUTES
}

\author{
Sergey Azemsha \\ Dept of Automobile Transportations and Road Traffic, Belarusian National Technical University, \\ Independence avenue 65, Minsk, Republic of Belarus, tel. +375297361860 , \\ E-mail: s-azemsha@yandex.ru
}

Received 20 December 2005; accepted 28 March 2006

\begin{abstract}
The increase of the efficiency of international car transportation of cargoes is an actual problem. For the solution to delivery problems at present the information systems on the basis of INTERNET-technology are created, containing information on cargo transportation and available free car transport facilities. This allows somewhat to solve a problem of loading a transport facility in an inverse direction. Thus, there is a task of the acceptance of an optimum decision concerning return loading. In this article the technique is presented, allowing to determine the waiting time of return loading of the vehicle working in any direction at which economic benefit of the performed job will be maximal.
\end{abstract}

Keywords: international transportations, automobile vehicles, return loading, waiting time, optimization, specific profit, efficiency, full run, operating ratio of run.

\section{Introduction}

At the present time in the market of transport services strengthening competition between different types of transport and between various enterprises of one type of transport is observed. The same position is characteristic of motor transport. Under the conditions of competition between carriers, the problem of the increase of efficiency of international automobile transportations becomes more and more urgent. The works of many scientists are devoted to the solution of this problem.

B. M. Napolsky in the work "Research of technical and economic questions of the organization of the international automobile transportations" [1] researched the aspects of economic efficiency of transportations, has offered a criterion and has developed a technique of definition of the sphere of expedient use of motor transport.

Questions of the increase of efficiency of transportations of cargoes are considered by N. I. Baranov in the work "The increase of the efficiency of transportation of cargoes between cities by motor transport of general using on the basis of collective forms of the organization of work" [2]. In the work on the basis of comparison of a percentage ratio of the integrated complex brigades of various types of transport and corresponding growth of labour productivity in primary labour collectives in comparison with specialized brigades, the introduction of the collective form of the organization of work proves in long-distance transportations. For the development and increase of the efficiency of collective forms of the organization of work N. I. Baranov suggests to develop passport lines and labour collectives, and also to improve the system of material encouragement of work with the use of a parameter of the efficiency of work.

Thomas Shnajderhajntse [3] was engaged in the questions of the increase of efficiency of international automobile transportations of cargoes. In the work "Increase of the efficiency of international transportations for motor industry with the use of motor transport" he considered logistical schemes of delivery of cargoes for motor industry in international transportations by motor transport. He put forward a maximum of production efficiency of cars as a criterion of efficiency [3]. In the subjects of optimization, influencing the value of the given criterion function Thomas Shnajderhajntse considers the scheduled period of the delivery of accessories sent by one set, and the number of mobile-complete set in a set. Using the given criterion function for the concrete enterprise of motor industry it is possible to define such values of operating parameters which would provide a maximum of criterion function. 
A. A. Dzhavadov in the work "Perfection of the system of operational planning of return loading of cars in long-distance" [4] shows the necessity of reforming the system of operational planning of return loading of automobile vehicles in the performance of long-distance automobile transportations of cargoes. In the work the problem of return loading of cars which are carrying out the transportation of cargoes in long-distance message is formulated. According to the statement of this task there are orders for transportation in longdistance message which daily receipt and process of their receipt in time are random variables. Each order is represented by obligatory requisites (departure time of a cargo of the certain weight, points of departure and purposes and also distance of transportation). Besides there is a park of automobile vehicles for the maintenance of return loading, the information which is represented in the form of the advancing information on forthcoming arrival of cars or in the form of the information on the arrived cars. The data about cars are also formed on the basis of obligatory requisites the moment of arrival of an automobile of the certain carrying capacity in destination, the place of its constant disposition and the distance between initial and final items. On the basis of available data about an offered cargo and vehicles there is an optimum plan of transportation of cargoes on routes of return loading so that specific working costs of the transportation of cargoes and on expectation were minimal. Thus a number of conditions should be satisfied: the deviation of the car from the basic route at return loading should not be above admissible size; the waiting time of the car of return loading should be not more than maximal admissible; the execution time of the order should not be more than admissible value and others. On the basis of the resulted data the operating plan of return loading of vehicles, meeting all the requirements of the statement of the task about return loading is formed.

The questions of the increase of efficiency of functioning of motor transport in international automobile transportations of cargoes were considered by K. H. Ahmedov. He has divided the process of functioning of motor transport in international transportations into two subsystems: international transportation of cargoes and automated control system (MANAGEMENT information system) of international transportation of cargoes [5]. He tried to reach the increase of overall performance of motor transport in international transportations due to the acceleration of delivery of cargoes. So, a subsystem "international transportation of cargoes", in his opinion, can be accelerated due to the reduction of expenses of time for the preparation of a cargo for transportation, to the expectation of departure, to loading, unloading, run with a cargo, etc. Modelling each separate element of a transport process, he reduces the total time of delivery of a cargo. In the formation of a subsystem (MANAGEMENT information system) for international transportation of cargoes he solves the task of the choice of the most rational speed of movement of vehicles. He solves this problem by splitting the route of vehicles into sites, with characteristic conditions of movement and normalization of speed in them.

V. V. Konstantinov in the work "Increase of the efficiency in the interregional and interrepublican message on the basis of the method of centralized operative management" [6] saw the increase of the efficiency of automobile transportation of cargoes as the increase of the efficiency of automobile transportation of cargoes in the centralization of their management. In the work three kinds of centralization of operative management are considered: zone, regional, hierarchical. Carried out researches have shown that the centralization of all functions of operative management increases the speed of decisionmaking and also increases the overall performance of motor transport and provides a regional kind of centralization of operative management. The primary goal of the centralized management is certain operative and optimum fastening of irregular freight traffics for available truckstream. Thus as the criteria of optimality maximization of operating ratios of carrying capacity and run of vehicles is offered, and their product is named [6] "dynamic operating ratio of carrying capacity". Cost indexes are not considered as it is necessary, that specific expenses for transportation will be less than the value of dynamic operating ratio of carrying capacity of all cars borrowed in the system. Thus, the decision of the problem is reduced to the maximization of a dynamic operating ratio of carrying capacity.

V. F. Levin's work “The increase of the efficiency of long-distance transportation of cargoes on the basis of the use of routing parameters of a transport process" [7] is devoted to the increase of efficiency. The work is based on the criticism of the use of identical average values of norms of time for the performance of elements of a transport process on various routes and it is offered to allocate the values of average norms of time for these elements for each route. Thus the reception of numerical values of parameters of a transport process by mathematical modelling of the movement of vehicles is considered. For this purpose it is offered to use the passport of a route in which features of the movement of cars should be reflected in this route.

The ways of the increase of the efficiency of international automobile transportation of cargoes are considered in the work "The increase of the efficiency of cargoes international transportation" [8]. In this work it is offered to optimize, first of all, high-speed modes of the movement of vehicles. With this purpose the factors influencing the speed of the movement of cars are allocated, and their movement is modeled. Thus, 
the speed of the movement of cars on routes is optimized. In the same work the search of ways of the increase of international automobile transportation of cargoes in the field of operational planning and management is made. In the work on the basis of the statement [8], that "volumes of transportation under each scheme of delivery, technical and operational parameters of transport and cargo handling means, senders and consumers of cargoes are set and it is required to place means and to allocate volumes of transportation of cargoes on time between senders and consumers that the minimum of the total resulted expenses as a whole in considered object" was provided deducting the function of total expenses which is necessary for minimizing. Besides the author considers the problem of adjusting influence (the change of sequence of loading-unloading, readdressing of a cargo and other cargo operations) with the purpose of maintenance of the coordination of time of the approach of cars and clearings of points of loading-unloading. That is, on the basis of forecasting the status of cars and the situation at the points of departure of a cargo it is offered to increase the intensity of loading (unloading) of cars, to make readdressing of cargoes, to change the sequence of reception, etc. so that the summary charges were the least. For the decision of the task in view minimization corresponding function is considered.

The original approach to the increase of the efficiency of functioning of motor transportation enterprises, which are carrying out international transportation, is offered by I. V. Domnin [9]. In the work the basic directions (routes) of job of automobile carriers are considered and for economic reasons the most rational of them are certain. Transportations are carried out between the countries of the European Union. Then the criterion, allowing to make the proved admission of the Russian carriers on the market of transport services of the countries of the European Union is offered. That is, the author offers "to win" a segment of the most profitable market of transport services due to the application of vehicles responding to the last ecological and road standards.

Chinese scientist Tsao Tsjun Sin investigated statistical regularities of separate elements, of a transport process for the conditions of the People's Republic of China and has defined their influence on the speed of delivery of cargoes [10]. The result of his scientific researches was the technique of likelihoodstatistical modelling of time of delivery of cargoes in international automobile transportation. The application of the technique allows to carry out likelihood planning of transportation on technology "precisely in time" with the estimation of guaranteed time of delivery. Due to this it is obviously possible to increase the reliability of the performance of concluded contracts.
The offered actions on the increase of the efficiency of the main automobile transportation of cargoes in the majority are directed to the optimization of existing schemes of connection between a cargo-sender and a cargo-addressee. In the given work the actual problem of decision-making concerning variants of loading of vehicles (including in the opposite direction) is not solved in international transportation of cargoes on the basis of the achievement of peak efficiency from the transport activity of a carrier.

\section{Statement of a task}

The practical problem solved in the given scientific article can be formulated as follows: an automobile carrier carries out the transportation of cargoes from country $X$ to country $Y$. Thus, there is a set of various variants of loading of an automobile vehicle, each of which is characterized by technical, operational and economic parameters. It is necessary to generate such route of transportation of cargoes, the effect from the job of which would be the greatest. But there is a natural question-what will act as a measure of quantity of the effect? So is it is necessary to establish a criterion of efficiency. In references a number of such criteria is offered: quantitative characteristics of transportation process in the form of separate technical, operational or economic parameters of the use of vehicles [11]; parameters defining the efficiency of separate cycles of the process of transportation (timeliness of delivery, speed of delivery, etc.) [12]; parameters of integrated efficiency (the resulted economic expenses, specific labour input of a complex of transport and technological operations, etc.) [12]. However, the known criteria are not focused on the account of interests of a carrier by the optimization of the sequence of transportation and the substantiation of the duration of expectation of return loading. As such criterion it is offered to accept the maximum of the specific profit received from transportation by an automobile vehicle for a time unit on one ton of its carrying capacity, that is [13]:

$$
P_{S}=P /(T q) \rightarrow \max ,
$$

where $P_{S}$-specific profit for a time unit on one ton of carrying capacity, BYR/(th);

$P$ - profit of a carrier on realization of transport services on transportation of cargoes, BYR;

$T$-car-days (hours) necessary for the performance of transport services on transportation of cargoes;

$q$ - carrying capacity of an automobile by which transportation is carried out.

In the developed kind the given expression will become [13]: 


$$
P_{s}=\frac{V_{t}\left(L_{f r}\left(\beta \cdot d_{s}-S_{\mathrm{var}}\right)+T_{i t} \cdot d_{i t}\right)}{q\left(L_{f}+\beta V_{t}\left(t_{l u}+t_{c}+T_{i t}+T_{e}\right)\right)}-\frac{S_{c o n s t}}{q},
$$

where $V_{t}$-technical speed of movement of a vehicle; $L_{f r}$ - run of an automobile vehicle with a cargo, during job on a route;

$\beta$-operating ratio of run of an automobile vehicle; $d_{s}$-specific proceeds for a unit of run. It depends on carrying capacity of an automobile vehicle demanded for transportation and can be approximated by linear dependence $d_{s}=a_{0 s}+a_{1 s} q_{d}$;

$S_{\mathrm{var}}$-variable expenses for a unit of run. These expenses depend on carrying capacity of a vehicle and its actual use and can be expressed as:

$S_{\mathrm{var}}=a_{0 \mathrm{var}}+a_{1 \mathrm{var}} q\left(1+a_{2 \mathrm{var}} \beta \gamma_{s t}\right)$;

where $T_{i t}$-expected paid time of the above permitted standard idle time under cargo operations at fault of the customer;

$d_{i t}$ - payment for a time unit of the above permitted standard idle time under cargo operations at fault of the customer. It can be presented also by linear dependence on carrying capacity of a demanded automobile vehicle $d_{i t}=a_{0 i t}+a_{1 i t} q_{d}$;

$t_{l u}$ - standard time of loading-unloading of an automobile vehicle;

$t_{c}$ - expected duration of idle time at the control and documentary registration of transportation (at customs, etc.);

$S_{\text {const }}$ - constant expenses for a time unit of job. These expenses depend basically on carrying capacity of an automobile vehicle $S_{\text {const }}=a_{0 \text { const }}+a_{1 \text { const }} q$;

$T_{e}$ - prospective duration of expectation of passing loading;

$q_{d}$ - carrying capacity of the demanded (declared) automobile vehicle $\left(q_{d} \leq q\right)$.

In the scientific researches [14] it has been established that operated parameters in the expression of specific profit will be demanded by carrying capacity $\left(q_{d}\right)$, operating ratio of run $(\beta)$, run of an automobile vehicle with a cargo $\left(L_{f r}\right)$ and waiting time of return loading $\left(T_{e}\right)$. That is each probable route of an automobile vehicle will be characterized by the operated parameters which will form in turn the value of the chosen criterion of efficiency - specific profit. Thus, the task of routing of international automobile transportation of cargoes is reduced to the choice from the set of alternative routes of job of such route, for the job of which values of operated parameters will provide maximum of specific profit. However, it is possible to put forward a hypothesis that one of operated parameters will influence the values of others. This influencing parameter is the waiting time of return loading. It is caused by the fact that with the increase of waiting time of return loading the number of probable variants of the performance of return run will increase. Thus, the task of routing international automobile transportation of cargoes is reduced to the definition of optimum value of waiting time of return loading at which the size of specific profit will be maximum.

\section{Formation of initial data}

Initial data for the decision of a task in view represent the set of shipping requests for cargoes between countries $X$ and $Y$ in direct and return directions for the examined period of time (for example for a week). The number of shipping requests is equal to direct direction $N_{x}$, and the number of applications in the opposite direction to $N_{y}$. In the given applications the following information should be reflected: number, month and time of occurrence of the application; number, month and time when the cargo will be ready for loading; initial and terminal points of transportation; the rate of the freight for transportation; demanded carrying capacity and type of a body of a vehicle. After that, it is necessary to simulate the job of automobile vehicles on all routes which can be received by combination $N_{x}$ of straight lines and $N_{y}$ of the return the run. It will allow to define the waiting time of return loading for each possible route of the job of an automobile from the following expression:

$$
T_{e}=t_{3}-t_{1}-\frac{l_{e r}}{24 l_{h a}}
$$

where $t_{3}$-date of shipment of a shown cargo;

$t_{1}$ - time of clearing of the vehicle from the previous transportation;

$l_{e r}$ - empty run under return loading;

$l_{h a}$ - hourly average run of an automobile vehicle. It is established by the research, that hourly average run of an automobile is $22 \mathrm{~km}$.

Those routes for which the waiting time of return loading is less than zero, it is not necessary to include the forming of probable routes of transportation in the set.

The urgency of the problem of the choice of possible routes is caused by the necessity of the exception of the influence of those transportations at which the performance unprofitability of transportation is obvious. For example, for some transportation in a direct direction $x_{i}$ one of possible\{probable $\}$ variants of return loading will be in the opposite direction $y_{i}$ with the value of waiting time $7,2 \mathrm{~h}$, full run of $3391 \mathrm{~km}$, 
operating ratio of run 0,83 and demanded carrying capacity $20 \mathrm{t}$. Alongside with such variant of return loading it is possible to offer the set of alternative variants among which $y_{i}$ will be with the value of waiting time of return loading equal to $22,7 \mathrm{~h}$, full run of $2398 \mathrm{~km}$, operating ratio of run 0,728 and demanded carrying capacity $20 \mathrm{t}$. Comparing these two variants, it is possible to note that the last is less effective on all the values of the operated parameters. Thus, despite of notorious inefficiency of some transportations, they will influence the dynamics of dependence of the operated parameters from the waiting time of return loading that will influence in turn the size of the optimum waiting time of return loading. For exception of the given problem it is necessary to consider only such transportation for which the value of a criterion of efficiency will be maximal for the given period of time. For this purpose all available transportations and their characteristics can be presented in the following way (Fig 1).

That is, all possible variants of the run are ordered on the increase of the waiting time of return loading separately for each destination (terminal point) of a straight line run. For every run the values of length run with a cargo, operating ratio of the run, demanded carrying capacity of a vehicle and of factor (criterion) of efficiency $\left(K_{e f}\right)$ are considered. The effectiveness ratio is a parameter which allows to compare various runs in view of all operated parameters. The comparison of the runs among themselves by means of separate parameters (for example of length run with a cargo or demanded carrying capacity) will not be adequate and for this purpose the concepts of effectiveness ratio are used. It is possible to use the specific profit as such factor, counted according to the expression (2).

The technique of the formation of initial data for the estimation of the influence of waiting time of return loading on other operated parameters is the following:

1. All the return runs at each terminal point of a straight line run are ordered on the increase of the value of the waiting time of return loading.

2. Value of specific profit for each possible route pays off.

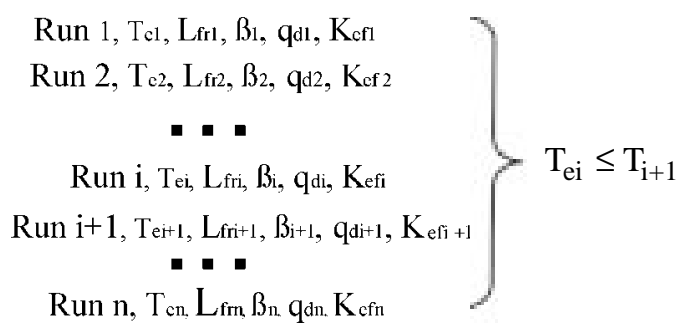

Fig 1. The grouping of initial data
3. Four files $\left(T_{e}, q_{d}, L_{f r}, \beta\right)$ are formed by such principle that to the first values of parameters of the specified four files sizes for a route with the minimal value of the waiting time of return loading are appropriated.

For each $i+1$-th and $i$-th run values $P_{s}$ are compared. If $P_{s i+1}>P_{s i}$ in the formed four files the following values of operated parameters are added. If $P_{s i+1} \leq P_{s i}$ it is necessary to increase value $i$ by unit that is to pass to viewing the following possible return run.

Algorithm initial data received as a result of the performance described above will show what maximal effect can be received depending on the waiting time of return loading.

The settlement of methods or methods of mathematical statistics are necessary to define $P_{s}$ value of such parameters entering into the expression of specific profit, as specific proceeds for unit of run, variable expenses for unit of run, payment for a time unit of above permitted standard, idle time under cargo operations on wait of the customer, constant expenses for a time unit of job.

\section{Technique of the definition of the optimum waiting time of return loading}

The definition of the waiting time of return loading is a task compromise. It is caused that on the one hand the increase of the waiting time of return loading leads to the increase of idle time of vehicles. It in turn affects the efficiency of a transportation process. On the other hand, with the increase at the waiting time of return loading, the number of alternative variants in the opposite direction increases. As a result such run can appear, the effect of which performance will bring a greater effect in comparison with any of earlier offered run. It is possible to assume that the curve of dependence of specific profit on the waiting time of return loading will increase to some optimum value $T_{\text {eopt }}$. The further expectation will bring the decrease of specific profit.

For the definition of the optimum waiting time of return loading in a considered direction of transportation of cargoes it is necessary to define the methods of mathematical statistics: the kind of dependence of length run with a cargo, operating ratio of run and demanded carrying capacity of a vehicle on the waiting time of return loading. Then, the received expressions are necessary for substituting in the expression of specific profit (expression (2)). From the expression received thus it is necessary to find a derivative of the waiting time of return loading and to equate it to zero. Received as a result of the decision of the given equation the root will give the optimum value of the waiting time of return loading. Thus it is 
necessary to consider only those roots which value is meaningful, that is, greater than zero (as time cannot be negative).

\section{Definition of the optimum waiting time of return loading working in the direction Belarus-Russia}

For the reception of the initial data the work of cargo automobile vehicles of various routes has been simulated. Routes of cargo automobile vehicles have been received on the basis of processing shipping requests of cargoes from the Russian Federation to Belarus, placed on a site www.belcargo.com during 13 December 2004 - 17 December 2004. The general set of the received routes of the job of vehicles made 1063 routes. By means of a package of statistical programs STATISTICA 6.0 the following dependences of operated parameters on the waiting time of return loading have been established:

$$
\begin{aligned}
& L_{f r}=2021,493-0,027 T_{e}^{2}+32,935 \sqrt{T_{e}} ; \\
& \beta=\frac{1}{1,365-0,09 \ln \left(T_{e}+1\right)+0,0009 T_{e}} ; \\
& q_{\mathrm{d}}=19,176+0,923 \ln \left(T_{\mathrm{e}}+1\right)-0,498 \sqrt{T_{\mathrm{e}}}+0,015 T_{\mathrm{e}} .
\end{aligned}
$$

Besides, carried out researches have allowed determining of the following dependences: specific profit on demanded carrying capacity:

$$
d_{s}=860,91+48,58 q_{d}
$$

variable expenses for a unit of run:

$$
S_{\mathrm{var}}=440,33+24,32 q(1+0,34 \beta \gamma) ;
$$

payment for a time unit of the above permitted standard idle time under cargo operations on wait of the customer:

$$
d_{i t}=11393,3+97,68 q_{d} ;
$$

constant expenses for a time unit of the work:

$$
S_{\text {const }}=670196+57,46 q .
$$

Having substituted expressions (4)-(10) in expression (2) it is possible to receive the expression of dependence of specific profit on the waiting time of return loading. Graphic interpretation of the given dependence is resulted in Fig 2.

Analyzing Fig 2 it is possible to draw a conclusion that the optimum waiting time of return loading for transportation between Belarus and the Russian Federation is 15 hours. The specific profit thus for the considered transportation makes the order $250 \mathrm{BYR} /(\mathrm{h} \mathrm{t})$.

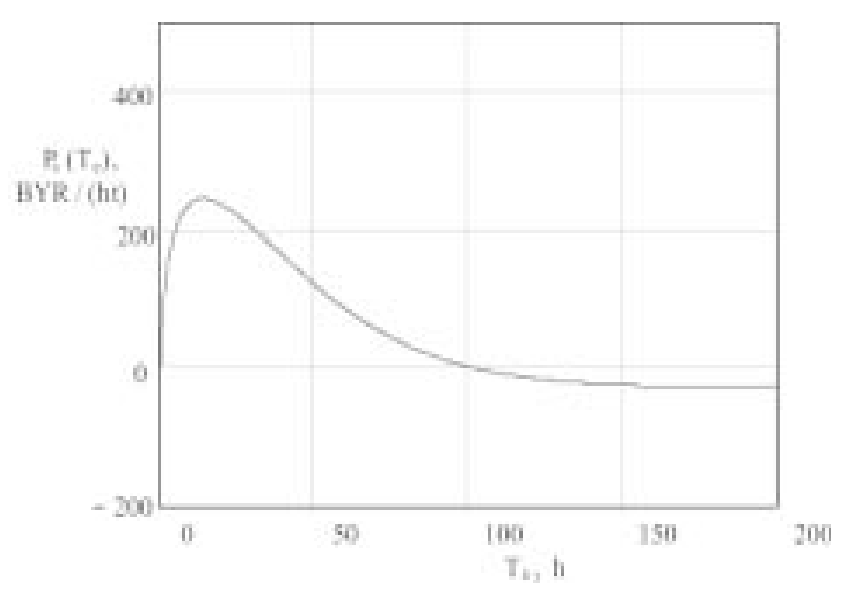

Fig 2. Dependence of specific profit on the waiting time

\section{Conclusion}

Summarizing it is possible to note that the considered problem of the increase of the efficiency of international automobile transportation of cargoes is rather actual. The analysis of references has shown that there are no techniques, allowing to define the proved terms of expectation of return loading of vehicles. In the given article the technique is suggested allowing to define such waiting time of return loading at which the value of the chosen criterion of efficiency (specific profit) will be maximal.

The example of practical application of the offered technique shows that for transportation between Belarus and the Russian Federation the optimum waiting time of return loading makes approximately $15 \mathrm{~h}$. It will correspond to specific profit of equal $250 \mathrm{BYR}$ for one hour of each ton of carrying capacity of a vehicle.

\section{References}

1. Napolskiy, B. M. Research into technical and economic questions of the organization of international motor transportations. Abstract of the candidate of science dissertation (Исследование технико-экономических вопросов организации международных автомобильных перевозок. Автореферат диссертации на соискание степени кандидата технических наук). Moscow, 1974. 20 p. (in Russian).

2. Baranov, N. I. Increase of the efficiency of longdistance transportations of cargoes by motor transport of common using on the basis of collective forms of the organization of work. Abstract of the candidate of science dissertation (Повышение эффективности междугородных перевозок грузов автомобильным транспортом общего пользования на основе коллективных форм организации труда. Автореферат 
диссертации на соискание степени кандидата технических наук). Moscow, 1986. 19 p. (in Russian).

3. Shnajderhajntse T. Increase of the efficiency of international transportations for motor industry with the use of motor transport. Abstract of the candidate of science dissertation (Повышение эффективности международных перевозок для автомобилестроения с использованием автомобильного транспорта. Автореферат диссертации на соискание степени кандидата технических наук). Minsk, 2003. 20 p. (in Russian).

4. Dzhavadov, A. A. Perfection of the system of operational planning of return loading of cars in longdistance message. Abstract of the candidate of science dissertation (Совершенствование системы оперативного планирования обратной загрузки автомобилей в междугороднем сообщении. Автореферат диссертации на соискание степени кандидата технических наук). Moscow, 1987. 16 p. (in Russian).

5. Ahmedov, K. H. Increase of the efficiency of functioning of motor transport on international transportations of cargoes (on example of enterprises „Sovavto-Termez" Abstract of the candidate of science dissertation (Увеличение эффективности функционирования автомобильного транспорта на международных перевозках грузов (на примере АТП МНП „Совавто-Термез”). Автореферат диссертации на соискание степени кандидата технических наук). Tashkent, 1990. 17 p. (in Russian).

6. Konstantinov, V. V. Increase of the efficiency of automobile transportations of cargoes in interregional and interrepublican message on the basis of the method of centralized operative management. Abstract of the candidate of science dissertation (Увеличение эффективности автомобильных перевозок грузов в межобластном и межреспубликанском сообщении на основе метода централизованного оперативного управления. Автореферат диссертации на соискание степени кандидата технических наук. Moscow, 1991.19 p. (in Russian).

7. Levin, V. F. Increase of the efficiency of long-distance transportations of cargoes on the basis of the use of routing parameters of a transport process. Abstract of the candidate of science dissertation (Увеличение эффективности междугородных перевозок грузов на основе использования маршрутных параметров транспортного процесса. Автореферат диссертации на соискание степени кандидата технических наук. Moscow, 1987. 17 p. (in Russian).

8. Kasymov, G. M. et al. Increase of the efficiency of international transportations (Повышение эффективности автотранспортных международных перевозок). Tashkent: Mehnat, 1990. 174 p. (in Russian).

9. Domnin, I. V. Development of the methods of the increase of competitiveness of the Russian enterprises which are carrying out the international automobile transportations of cargoes. Abstract of the candidate of science dissertation (Разработка методов повышения конкурентоспособности российских предприятий, выполняющих международные автомобильные перевозки грузов. Автореферат диссертации на соискание степени кандидата экономических наук). Moscow, 2003. 25 p. (in Russian).

10. Tsao Tsun' Sin. Development of international auto transportations of the People's Republic of China in conditions of market relations. Abstract of the candidate of science dissertation (Развитие международных автоперевозок КНР в условиях рыночных отношений. Автореферат диссертации на соискание степени кандидата экономических наук). Moscow, 2003. 20 p. (in Russian).

11. Zhitkov, V. A.; Kim, K. V. Methods of operational planning of cargo automobile transportations (Методы оперативного планирования грузовых автомобильных перевозок). Moscow: Transport, 1982. 183 p. (in Russian).

12. Vorkut, A. I. Cargo automobile transportations (Грузовые автомобильные перевозки). Kiev: Highest school, 1986. 447 p. (in Russian).

13. Azemsha, S. A.; Sedziukevich, V. N. Criteria of the optimality of routing the main automobile transportation of cargoes in view of different time sendings. In: Materials of 2-nd international scientific and technical conference "The science - to education, manufacture, economy", Vol 1 (Материалы 2-й международной научнотехнической конференции „Наука - образованию, производству, экономике”, том 1), Minsk, BNTU, 2004, p. 279-281 (in Russian).

14. Azemsha, S. A. Choice of operated parameters of a criterion of efficiency of international cargo automobile transportations. In: Proceedings of the 8-th conference of young scientists of Lithuania "Lithuania without science - Lithuania without future. Transport" (Aštuntosios Lietuvos jaunųjų mokslininkų konferencijos „Lietuva be mokslo - Lietuva be ateities“, ịvykusios Vilniuje $2005 \mathrm{~m}$. gegužès mèn. 12 d., pranešimų rinkinys. Transportas). Vilnius: Technika, 2005, p. 306-310 (in Russian). 